\title{
The Experimental Research on Special Polymerized Sulfur Composite- Impregnated Concrete and Cement Mortar
}

\section{Książek M*}

Wrocław University of Technology, Institute of Building Engineering, Division of Building Materials, Timber and Monumental Heritage Structures, Wroctaw, Poland

\begin{abstract}
Specific chemical environments step out in the industry objects. This paper presents experimental investigation results of the chemical resistance of special polymerized sulfur composite impregnated concrete and cement mortar. The special polymerized sulfur composite applied as the industrial waste material.

The process of special polymerized sulfur composite as the industrial waste material production is a thermal treatment process in the temperature of about $150-155^{\circ} \mathrm{C}$. The result of such treatment is special sulfur composite in a liquid state. Special sulfur composite in a liquid state is mixed with previously heated extender. In the paper there is presented development of the special polymerized sulfur composite as the industrial waste material, along with the practical uses in building industry. Also this paper presents the results of the experimental research and analyses indicating the usefulness of special polymerized sulfur composite to the protection against corrosion of concrete and cement mortar.
\end{abstract}

In this paper the review of the literature have been done, among other things about select using special polymerized sulfur composite in buildings, about the methods of the surface protection against corrosion of concrete and about the methods of the evaluation of protection layer on these materials. Also in paper presents materials also the domain of the personal investigations and the methodology are definite.

The research has comprised the compositions and the conditions for the formation of materials. The physical and mechanical properties of special polymerized sulfur composite have been evaluated.

After the analysis of the initial results the optimum compositions have been chosen to the experimental research. In this paper the usefulness of special polymerized sulfur composite to the surface protection against corrosion of the concrete and cement mortar have been evaluated.

Special polymerized sulfur composite impregnation of lean concrete and cement mortar increases its compressive strength from less than $1 / 3$ to 1-1/2 times that of high strength concrete. Maximum absorption of special polymerized sulfur composite is achieved by carrying out the impregnation in molten sulfur under vacuum. Recent work indicates that satisfactory impregnation levels may also be achieved without the use of vacuum. Studies also show that while impregnation of high strength concrete and cement mortar increases its final strength to a value higher than that of low strength concrete, the relative increase in strength and the amount of special polymerized sulfur composite absorbed are smaller. Special polymerized sulfur composite impregnated concrete and cement mortar (SIC) may be used where high strength, resistance to water penetration, chemicals etc. are required. Available impregnating technology is applicable to precast concrete and cement mortar structures, while suitable technology for impregnating cast-in-place concrete needs to be developed.

The impregnation of building materials such as blocks and bricks with melted special polymerized sulfur composite increases the compressive strength by a factor of 2 and modulus of elasticity by a factor of 3 . The permeability of special polymerized sulfur composite impregnated materials to water and salt solutions is also greatly reduced. Due to the large surplus of sulphur and the low price, special polymerized sulfur composite impregnation of building materials will find extensive use in tall building construction.

The space in concrete and cement mortar resulting from porosity reduces strength, exposes the concrete to chemical attack and, if filled with water, leads to destructive frost action at low temperatures. Filling the pores permanently and completely with an inert solid appears to be an effective way to improve mechanical properties and durability. Laboratory studies of impregnation with polymers have indicated that this is beneficial.

New developments in concrete and cement mortar special sulfur polymer materials have declined in the Poland. There are still many products that are widely used, but the growth of these materials seems to have stabilized. A brief summary of new products related to special sulfur polymer composite impregnation, repair, overlays and precast polymer concrete will be presented. Sulfur polymer composite impregnation, which has received little attention in recent years, currently has some very interesting applications. Repair materials, particularly low modulus sulfur polymer concretes, have proven to be very effective. An innovative overlay for use in areas where freezing and thawing is prevalent has been developed.

Keywords: Recycling; Chemical properties; Corrosion; Mechanical properties; Physical properties; Special polymerized sulfur composite

\section{Introduction}

Corrosion is a major problem from the social, economic, technical and scientific points of view. Despite extensive research and numerous papers on this subject, the problem has not been completely solved yet. It is estimated that in highly developed countries losses due to corrosion annually amount to about a thousand dollars per capita. In Poland they are estimated at $5-11 \%$ of the GDP, concern global economy [1-8].
*Corresponding author: Książek M, Wrocław University of Technology, Institute of Building Engineering, Division of Building Materials, Timber and Monumental Heritage Structures, pl. Grunwaldzki 11, 50-377 Wrocław, Poland, Tel: +48 71 32026 00; E-mail: ksiazekmariusz@wp.pl

Received January 20, 2015; Accepted March 12, 2015; Published March 24 2015

Citation: Ksiażek M (2015) The Experimental Research on Special Polymerized Sulfur Composite-Impregnated Concrete and Cement Mortar. J Material Sci Eng 4 160. doi: $10.4172 / 2169-0022.1000160$

Copyright: (c) 2015 Książek M. This is an open-access article distributed under the terms of the Creative Commons Attribution License, which permits unrestricted use, distribution, and reproduction in any medium, provided the original author and source are credited. 
Corrosion contributes to the shortening of the service life of building structures, i.e. to a reduction in their capability to perform the required functions over a given period of time [9-15].

Corrosion affects practically all building materials, not only steel, concrete or reinforced concrete (of course, no building material, structural element or building is everlasting). Generally speaking, the fight against corrosion comes down to providing a given material or element with protection whereby its failure free service life is significantly extended [16-21].

In order to demonstrate the suitability of special polymerized sulfur applied as the industrial waste material for the surface protection of concrete and cement mortar experimental research was carried out in the Institute of Building Engineering at Wrockaw University of Technology [22-34].

Properties of the elementary sulfur have been known for years. In the articles [1,35-41], they are already precisely described.

In the paper presents the personal investigations and the methodology for special polymerized sulfur - impregnated concrete and cement mortar applied as the industrial waste material to industries objects. After the analysis of the initial results the optimum special polymerized sulfur compositions have been chosen for the experimental research in the industries objects [1,35-41].

Some specific environments with varied corrosivity occur in industries objects. Soil with varied composition, structure and corrosivity, chemical relationships and chemical substances, organic environment of industries buildings, and the atmosphere of industries objects manufacturing plant protectives and fertilizers are among the most significant [42-51].

As far as construction made of reinforced concrete is concerned the corrosivity of industries building environment is much higher than that typical for rural one and it may be compared to that of atmosphere of chemical industry [52-58]

It depends on humidity and on concentration of compounds which make electrical conductivity of the condensate to increase and react chemically (battle chemicals and the battle relationship) with after that they have dissolved in it [59-66].

There are several ways possible of protecting ferroconcrete industries constructions: pre-galvanizing steel, using alloy steel, cathodic protection, electrochemical extraction of chlorides, realkalizing carbonated concrete. Protective coating, if needed, can be used to prevent corrosion of reinforcing steel, e.g. when concrete lagging may not to be tight, too thin or none, on connecting parts of precast concrete units. Special polymerized sulfur - impregnated concrete and cement mortar applied as the industrial waste material may be an example.

Experimental research of concretes and cement mortars impregnated with special polymerized sulfur applied as the industrial waste material has been attempted $[67,68]$.

In paper presents the personal experimental investigations and the methodology for special polymerized sulfur - impregnated concrete and cement mortar applied as the industrial waste material to industries objects.

At ambient temperature special sulfur applied as the industrial waste material crystallizes in the rhombic system ( $\alpha-S)$. It melts at the temperature $105-110^{\circ} \mathrm{C}$ and crystallizes from this melt to the form of
$\beta-S$ (monociclic) which changes again to the $\alpha-\mathrm{S}$ at $95-96^{\circ} \mathrm{C}$ as discussed elsewhere [64,65].

Melted sulfur polymerizes applied as the industrial waste material in the industries objects as discussed and published elsewhere [56-67]:

$>155-160^{\circ} \mathrm{C}$ it is brown and indicates increased viscosity,

> between 200 and $250^{\circ} \mathrm{C}$ it is dark brown with high viscosity value,

$240-250^{\circ} \mathrm{C}$ depolimerization and diminishing of viscosity begins; at $400^{\circ} \mathrm{C}$ sulphur is very fluid,

$>\quad 443-444^{\circ} \mathrm{C}$ is the temperature of its boiling. The rapid process of cooling sulfur in water changes it from fluid state to an elastic-plastic body, brown-yellow coloured. In this state sulfur is composed of two different polymerized forms: $S_{\lambda}$ (yellow) and $S_{\mu}$ (dark red-brown). $S_{\mu}$ has a higher molecular mass.

Sulfur may be obtained in the colloidal state as discussed elsewhere [56-67]:

$$
\begin{aligned}
& >\text { after boiling with water and } \mathrm{Ca}(\mathrm{OH})_{2} \text { and precipitation with } \\
& \mathrm{HCl}-\mathrm{S}_{\mu} \\
& >\quad \text { after hydrolysis of alcohol solution }-\mathrm{S}_{\lambda} \text {. }
\end{aligned}
$$

From the chemical reactivity point of view, sulfur may be oxidised and as well easy reduced (it forms many sulphides and organo-sulphur compounds). Elementary sulfur finds rarely applications. It is used to the production of some kind of cement for special purposes, e.g. to join ceramics and metalics parts of electric insulators and in the industries objects. The mechanical properties of this cement are good (strength about 45-50 MPa by compression), and its chemical inertness is appreciated (in comparison to the Portland cement containing concretes). Sulfur is also used in dermatology as discussed elsewhere [1,33-35,68].

Functional properties of the special polymerized sulfur and sulfur polymer based products as discussed and published elsewhere [39-51]. Orthorhombic special polymerized sulfur is also subject to deterioration by bacteria, sunlight, very strong alkalies, and thermal fluctuations $[1,33-35,68]$.

\section{Samples and Methods}

Special polymerized sulfur applied as the industrial waste material were investigated in two stages. In the first stage, compositions were fixed and thirty test special sulfur were prepared and pretested. The pretesting included preparing special polymerized sulfur and determining their basic physical and mechanical properties, such as: bulk density, absorbability by wt., bending strength and splitting tensile strength.

The special polymerized sulfur as the industrial waste material view of the Figure 1a and 1b. Special polymerized sulfur applied as the industrial waste material in the industries objects were investigated in two stages. In the first stage, compositions were fixed and thirty test special polymerized sulfur were prepared and pretested.

The compositions of the binder-sulphur applied as the industrial waste material: $97.86 \% \mathrm{~S}_{8}$, fine sulfur, oil: $2.13 \%$, the ash: $0.01 \%$, producer "Siarkopol" Tarnobrzeg. The special polymerized sulfur applied as the industrial waste material view of the Figures $1 \mathrm{a}, 1 \mathrm{~b}$ and 2 .

When fixing the compositions, the special polymerized sulfur: $97.86 \% \mathrm{~S}_{8}$, fine sulfur producer "Siarkopol” Tarnobrzeg. The pretesting 
included preparing special polymerized sulfur and determining their basic physical and mechanical properties, such as: bulk density, absorbability by wt., bending strength and splitting tensile strength. The experimental results are reported in detail in [56-67].
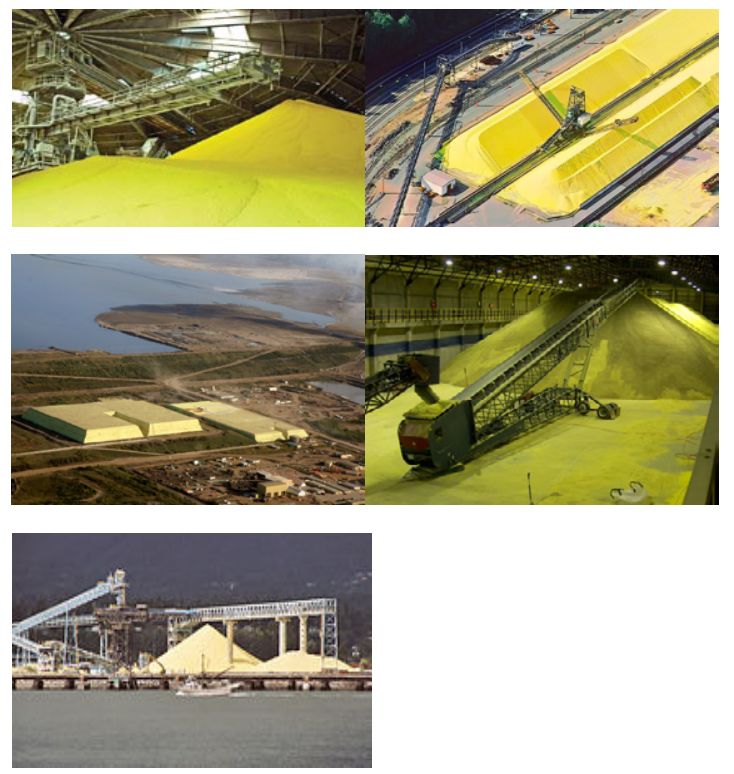

Figure 1a: A view of the special polymerized sulfur applied as the industrial waste material in Europe.
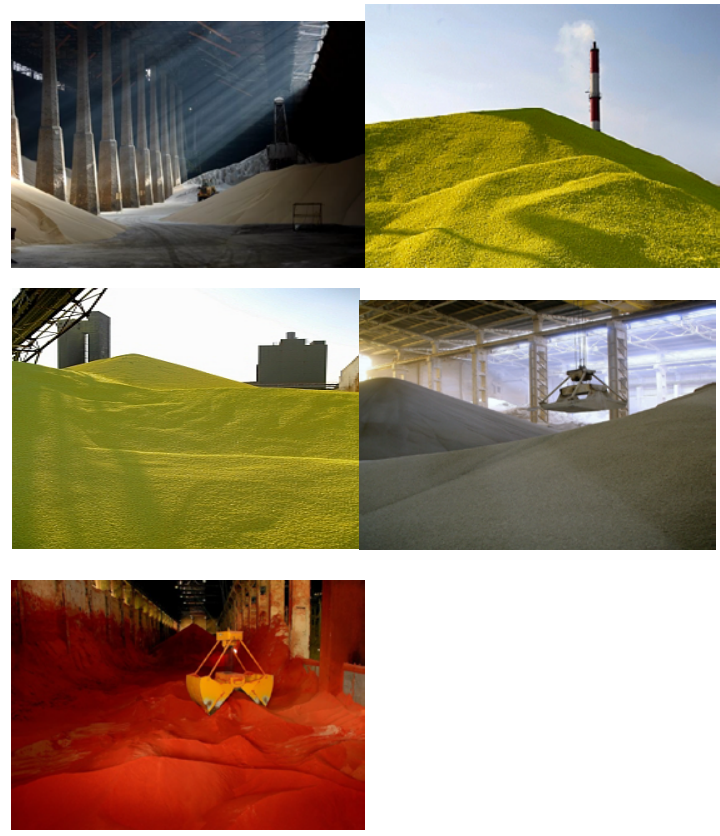

Figure 1b:A view of the special polymerized sulfur applied as the industrial waste material in Poland.
The results of the preliminary tests were analysed and the special polymerized sulfur in the industries objects having the best properties among the tested composites was selected for further studies. The basic information about the preparation of special polymerized sulfur is given in Table 1. The composition of the special polymerized sulfur applied as the industrial waste material in the industries objects is given in Table 2 and its experimentally determined properties are shown in Tables 3 and 4 .

The special polymerized sulfur applied as the industrial waste material view of the Figure 2. Chemical element of the special polymerized sulfur applied as the industrial waste material view of the Figure 3.

Cylindrical samples $35 \mathrm{~mm}$ in diameter and $38 \mathrm{~mm}$ in height and $10 \times 10 \times 60 \mathrm{~mm}$ and $40 \times 40 \times 160 \mathrm{~mm}$ rectangular samples were used to determine apparent density $\rho_{\mathrm{pm}}$ and water absorption by weight $\mathrm{n}_{\mathrm{wm}}$ of the polymer sulphur composite. $10 \times 10 \times 60 \mathrm{~mm}$ and $40 \times 40 \times 160 \mathrm{~mm}$ and $100 \times 100 \times 100 \mathrm{~mm}$ rectangular specimens were used to bending strength $\mathrm{f}_{\mathrm{dm}}$. Cylindrical samples $35 \mathrm{~mm}$ in diameter and $38 \mathrm{~mm}$ in height were used to determine tensile splitting strength $\mathrm{f}_{\mathrm{ctsp}}$. Cylindrical samples $35 \mathrm{~mm}$ in diameter and $38 \mathrm{~mm}$ in height and $10 \times 10 \times 60 \mathrm{~mm}$ and $40 \times 40 \times 160 \mathrm{~mm}$ and $100 \times 100 \times 100 \mathrm{~mm}$ rectangular specimens were used to determine compressive strength $\mathrm{f}_{\text {cmc }} \cdot 10 \times 10 \times 60 \mathrm{~mm}$ and $40 \times 40 \times 160 \mathrm{~mm}$ rectangular samples were used to determine longitudinal modulus of flexural elasticity $\mathrm{E}_{\mathrm{dm}}$ while cylindrical samples $35 \mathrm{~mm}$ in diameter and $38 \mathrm{~mm}$ and $40 \times 40 \times 160 \mathrm{~mm}$ in height were used to determine longitudinal modulus of compressive elasticity $\mathrm{E}_{\mathrm{cm}}$.

It was prepared by melting special polymerized sulfur at the temperature $150-160^{\circ} \mathrm{C}$ and then by cooling to the ambient temperature [56-67].

Impregnation Technique: The samples were immersed for 5-20 min. and remaining specimens for 0.5 hours in molten special polymerized sulfur. The specimens were then removed from the' steel vessel, and excess liquid sulphur on the surface was wiped off. The samples were cooled in water for 20 minutes in order to crystallize the sulfur in the surface pores and prevent loss of sulphur by evaporation, and were then left at room temperature to cool in the air. The specimens were weighed before and after impregnation and sulfur loading calculated. The impregnated specimens look shiny greenish to dark grey depending upon the original color of the specimens. However the rough texture is not very much affected. The total process time is 0.20 0.30 hours (20-30 $\mathrm{min})$ for samples. The samples concrete and cement mortar impregnated special polymerized sulfur binder applied as the industrial waste material view of the Figure 4.

\section{Investigation Results}

The viscosity of special polymerized sulfur as a function of temperature applied as the industrial waste material view of the Figure 5.

In 2008-2014 author reported on research with special polymerized sulfur - infiltrated concrete and cement mortar and noted that special sulfur has economic advantages over organic polymer. When the impregnation was vacuum assisted, an exceedingly strong and durable concretes and cement mortars could be produced by precasting.

\begin{tabular}{|c|c|c|c|}
\hline Binder & $\begin{array}{c}\text { Temperature of the polymerization } \\
\text { composite }\left[{ }^{\circ} \mathbf{C}\right]\end{array}$ & $\begin{array}{c}\text { Time of the polymerization composite } \\
{[\mathbf{m i n}]}\end{array}$ & $\begin{array}{c}\text { Time of coagulation of composite } \\
\text { [min] }\end{array}$ \\
\hline 1 & 2 & 4 \\
\hline special polymerized sulfur & $150-160$ & $40-60$ \\
\hline
\end{tabular}

Table 1: Basic information about the preparation of special polymerized sulfur. 
Citation: Książek M (2015) The Experimental Research on Special Polymerized Sulfur Composite-Impregnated Concrete and Cement Mortar. J Material Sci Eng 4: 160. doi:10.4172/2169-0022.1000160

Page 4 of 8

\begin{tabular}{|c|c|c|}
\hline \multicolumn{3}{|c|}{ Content in [\%] of total composite mass } \\
\hline Binder & Filler & Additive \\
\hline 1 & 2 & 3 \\
\hline $\begin{array}{c}\text { Sulfur } \mathrm{S}_{8} \\
{[\%]}\end{array}$ & Mineral quartz dust & Carbon black \\
\hline 100 & {$[\%]$} & - \\
\hline
\end{tabular}

Table 2: Composition of the special polymerized sulfur applied as the industrial waste material in the industries objects.

\begin{tabular}{|c|c|c|c|c|c|c|c|}
\hline $\begin{array}{c}\text { Average bulk } \\
\text { density } \rho_{p m} \\
{\left[\mathrm{~g} / \mathrm{cm}^{3}\right]}\end{array}$ & $\begin{array}{c}\text { Average } \\
\text { absorbability by } \\
\text { wt. } \\
n_{w m} \\
{[\%]}\end{array}$ & $\begin{array}{l}\text { Average bending } \\
\text { strength } \\
\boldsymbol{f}_{d m} \\
{[\mathrm{MPa}]}\end{array}$ & $\begin{array}{c}\text { Average splitting } \\
\text { tensile strength } \\
\qquad \boldsymbol{f}_{c t, s p} \\
{[\mathrm{MPa}]}\end{array}$ & $\begin{array}{c}\text { Average } \\
\text { compressive } \\
\text { strength } \\
\boldsymbol{f}_{c m c} \\
{[\mathrm{MPa}]}\end{array}$ & $\begin{array}{c}\text { Coefficient of } \\
\text { fragility } \\
k \\
{[-]}\end{array}$ & $\begin{array}{c}\text { Coefficient of } \\
\text { direct elasticity } \\
E_{d m} \\
\text { under bending } \\
\text { [GPa] }\end{array}$ & $\begin{array}{c}\text { Coefficient of } \\
\text { direct elasticity } \\
E_{c m} \\
\text { under compression } \\
\text { [GPa] }\end{array}$ \\
\hline 2.00 & $0.01-0.02$ & $\frac{10.0}{5.8 \%}$ & $\frac{3.0}{7.2 \%}$ & $\underline{50.0}$ & 0.90 & 60 & 65 \\
\hline
\end{tabular}

Note: the percentages under the line are coefficients of variation.

Table 3: Experimentally determined properties of special polymerized sulfur applied as the industrial waste material in the industries objects.

\begin{tabular}{|c|c|c|c|}
\hline Properities & Unit & Requirements & Test methods according to: \\
\hline Thickness of the impregnation & $\mathrm{mm}$ & from 0,2 to 0,6 & acc. to the technical sheets of the manufacturer \\
\hline Coat's adhesion to concrete* $)$ & $\mathrm{MPa}$ & $>1,0$ & PN-EN 1542:2000 \\
\hline Diffusion resistance for steam*) & $\mathrm{m}$ & $<1,2$ & PN-EN ISO 7783:2001 \\
\hline Diffusion resistance for carbon dioxide*) & $\mathrm{m}$ & $>50$ & Test procedure ITB Nr LO-6 \\
\hline Water penetration coefficient $\left.{ }^{*}\right)$ & $\mathrm{kg} /\left(\mathrm{m}^{2} \mathrm{~h}^{0,5}\right)$ & $<0,1$ & PN-EN 1062-3 \\
\hline $\begin{array}{l}\text { Resistance to action of } 150 \text { cycles of freezing and defrosting in water } \\
\text { and } \mathrm{NaCl} \text { solution*) }\end{array}$ & - & no changes in the coat & IBDiM Test Procedure No. SO-3 Visual valuation \\
\hline Coat's adhesion to concrete after testing frost resistance as above *) & $\mathrm{MPa}$ & $>1,0$ & IBDiM test procedure No. SO-3 PN-EN 1542:2000 \\
\hline
\end{tabular}

* for coats 1.0-1.5 mm thick

Table 4: Characteristics of special polymerized sulfur composites - impregnated concrete and cement mortar applied as the industrial waste material in the industries objects.
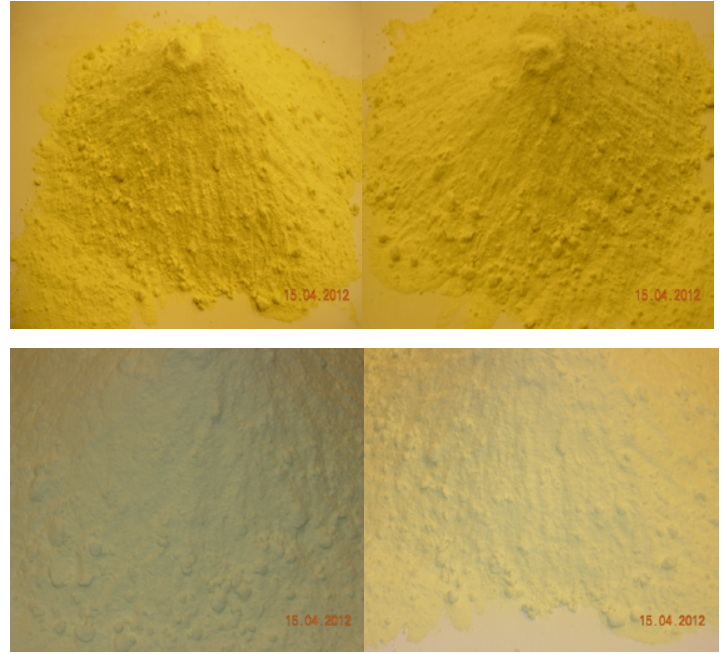

Figure 2:A view of the special polymerized sulfur binder applied as the industrial waste material.

Author did not recommend his particular formulation for cast-inplace use. In effect, the special sulfur was used as a substitute for some of the Poland cement, because the concrete and cement mortar, being infiltrated, had a water-cement (w/c) ratio of 0.70 about $4.0 \mathrm{bag} / \mathrm{yd} 3$. In 2008-2014 it was concluded that at least in Poland this infiltrated concrete and cement mortar would probably be less costly than Poland cement concrete having a $\mathrm{w} / \mathrm{c}$ of 0.40 . The sulfurinfiltrated concrete had a compressive strength of over $0,000 \mathrm{lb} . / \mathrm{in} .2\left(700 \mathrm{~kg} / \mathrm{cm}^{2}\right)$, withstood 200 cycles of freezing and thawing without damage, and

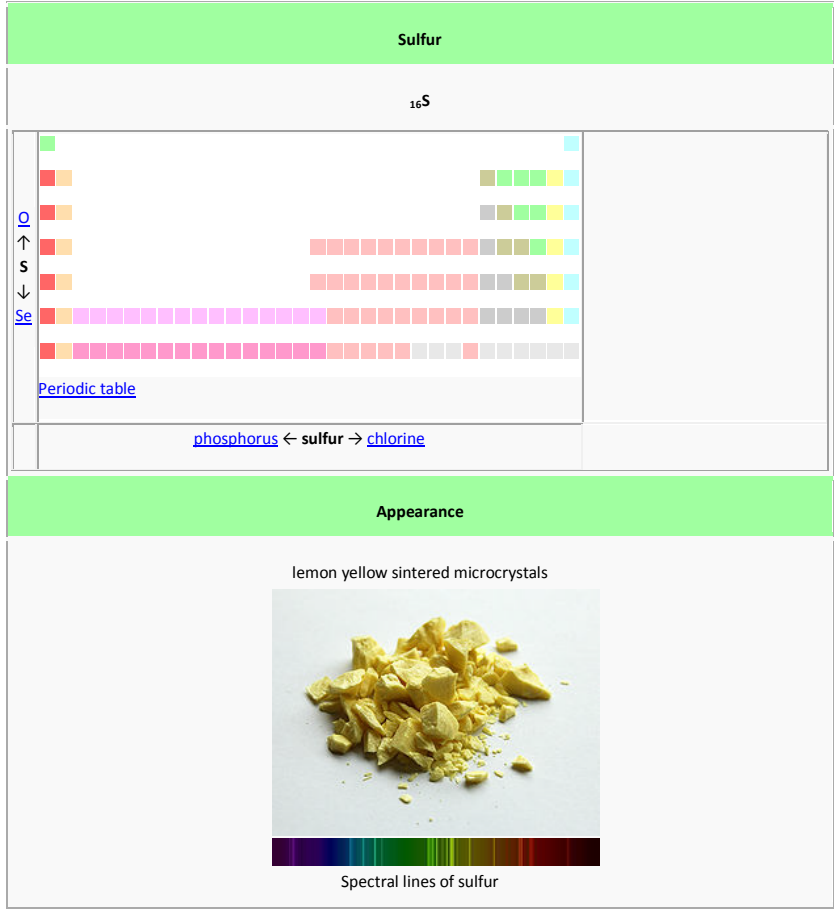

Figure 3: Chemical element of the special polymerized sulfurapplied as the industrial waste material.

was exceedingly resistant to chemical attack. Apparently, the special polymerized sulfur fills the capillaries and prevents absorption of water 
Citation: Książek M (2015) The Experimental Research on Special Polymerized Sulfur Composite-Impregnated Concrete and Cement Mortar. J Material Sci Eng 4: 160. doi:10.4172/2169-0022.1000160

Page 5 of 8
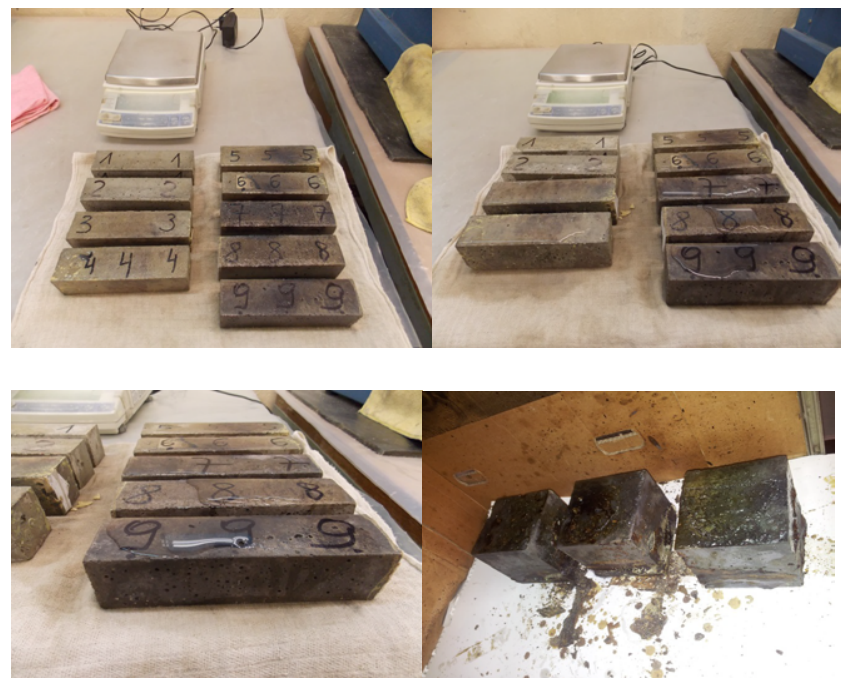

Figure 4: A view of the samples concrete and cement mortar impregnated special polymerized sulfur binder applied as the industrial waste material. A view natural surface of ordinary cement mortar and concrete impregnated special polymerized sulfur composite applied as the industrial waste material.
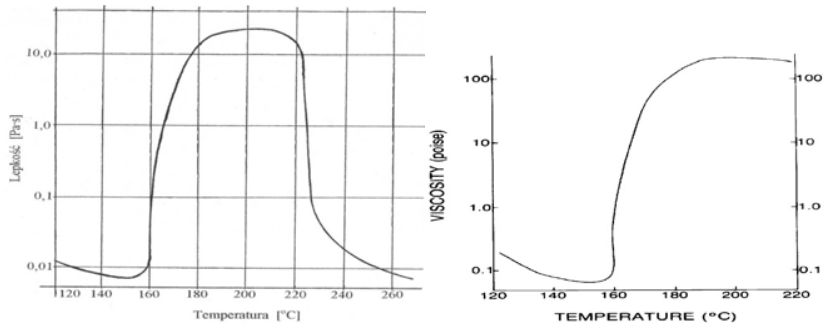

Figure 5:Viscosity of special polymerized sulfur as a function of temperature.

or chemicals and this prevents the critical saturation that causes freezethaw distress. A personal communication from author indicated that there had been no change in the properties of this laboratory concrete in five years.

The tremendous increase in properties was offset by the complexities of the impregnation process: drying to remove all of the moisture, evacuating the air, applying the special polymerized sulfur under pressure to fully impregnate the concrete, and the application of heat or irradiation to fully polymerize the monomer. To fully impregnate large precast components such as several city collectors, bridge girders, bridge deck slabs, piling, and wall panels would require a large, efficient facility that would be difficult to justify unless it could be shown that a market for a large volume of PIC products would be forthcoming. No such facility has ever been developed in the Poland. Until some breakthroughs in process technology are realized, there is little likelihood that fully-impregnated PIC members will ever become economically feasible. This is unfortunate since PIC has such exceptional strength and durability properties.

A view of the municipal collector's sewer impregnated special polymerized sulfur applied as the industrial waste material is presented in Figure 6. The view of studied concretes samples was showed on Figure 7. The Composition of cement concretes of city sewer collector's impregnated special polymerized sulfur is presented in Table 5.
Research was also successful in developing processes for partial depth impregnation that could be used in the field for impregnating bridge decks and other concrete and cement mortar surfaces. The process required drying the concrete to remove moisture from the surface, applying the special polymerized sulfur on a thin sand layer that held the special polymerized sulfur during the time the monomer
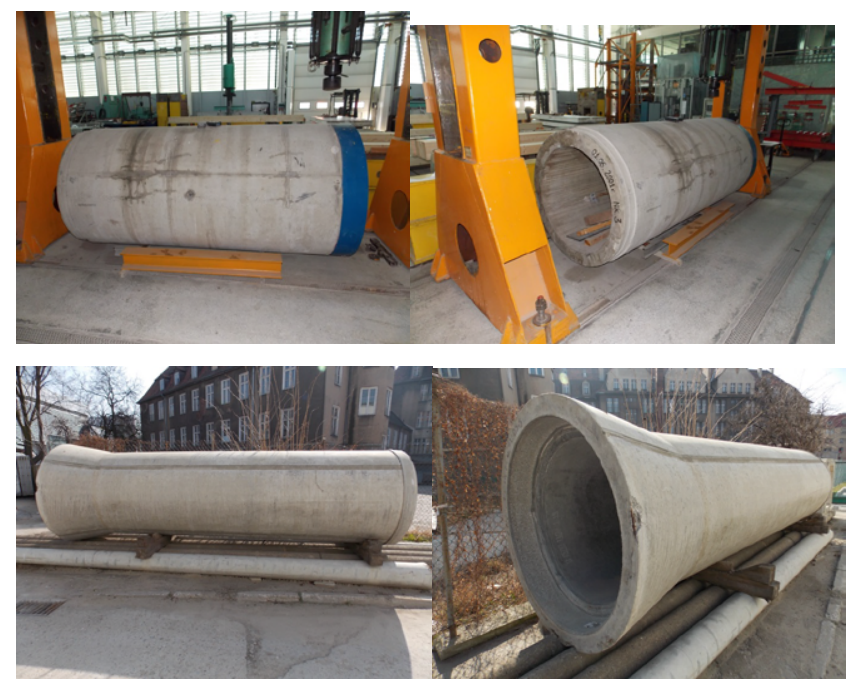

Figure 6: A view of municipal collector's sewers. The city sewer collectors were impregnated special polymerized sulfur applied as industrial waste materials.
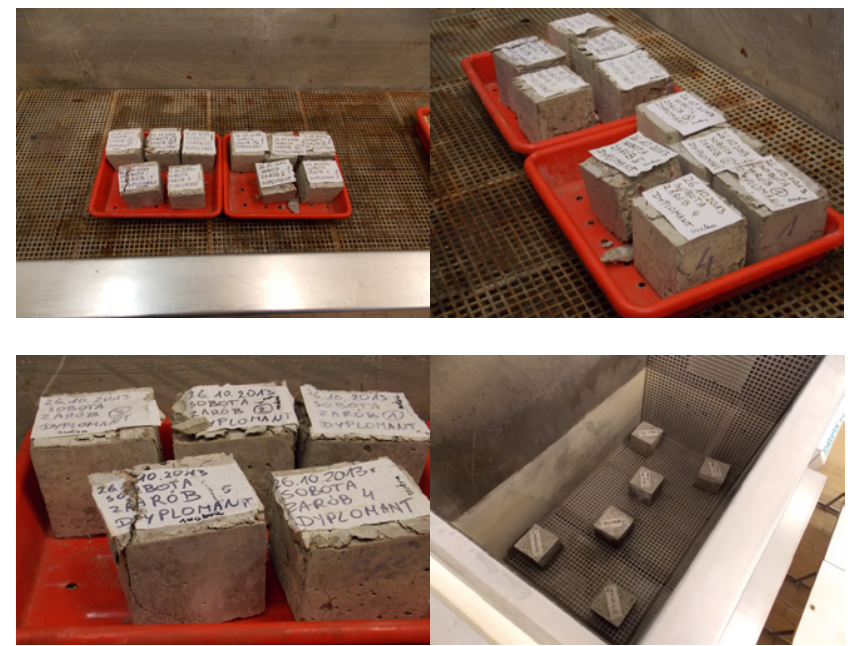

Figure 7: A view of concrete samples. The concrete samples were impregnated special polymerized sulfur applied as industrial waste materials.

\begin{tabular}{|l|c|}
\hline \multicolumn{1}{|c|}{$\begin{array}{c}\text { Cement concrete constituent materials } \\
{\left[\mathbf{k g} / \mathbf{m}^{3}\right]}\end{array}$} & $\begin{array}{c}\text { C30/37 } \\
\text { (B37) }\end{array}$ \\
\hline Aggregate 0-2 mm & 760 \\
\hline Aggregate 2-8 mm & 332 \\
\hline Aggregate 8-16 mm & 674 \\
\hline CEM I 32,5R & 372 \\
\hline Water & 212 \\
\hline w/c & 0.57 \\
\hline
\end{tabular}

Table 5: The composition of just concretes of city sewer collectors impregnated special polymerized sulfur. 
was being imbibed into the concrete, and then polymerizing the monomer using steam heat. The process was capable of producing impregnated depths of 10 to $60 \mathrm{~mm}$. The concrete surfaces were much more resistant to water absorption, had much higher abrasion resistant, and in generally were much more durable. The downside was that the process normally took about one day and subjected the concrete to high temperatures during drying that resulted in micro cracking, and was rather cumbersome. Many bridge decks in the Poland were successfully impregnated during the 1980-1985, but the development of polymer concrete overlays provided a simpler, faster and less costly method for waterproofing concrete surfaces.

More recently, however, there has been a successful commercial application of partial depth impregnation. The special polymerized sulfur vacuum impregnation system uses a plastic membrane that is applied over the surface of a slab, statue, column or wall and vacuum to evacuate the air from the pores.

\section{Summary and Conclusion}

It can be concluded from the test results that the tested special polymerized sulfur composite can provide surface corrosion protection in concrete and cement mortar. Special polymerized sulfur composite has not been applied for this purpose before. The tests have shown that a proper thickness of the special polymerized sulfur composite and the type of surrounding corrosion environment are important factors here.

The test results presented in this paper and discussed elsewhere indicate that the special polymerized sulfur composite - impregnated concrete and cement mortar applied as the industrial waste material can provide surface protection against corrosion for concrete. Special polymerized sulfur composites have not been used for this purpose before.

The authors are aware that although the range of the tests carried out so far is quite wide, still further tests are needed to ultimately determine the suitability of the special polymerized sulfur composite for the surface protection of the concrete and cement mortar against corrosion. Also a simple and practical technology of applying this material (polymer) to the surface of concrete and cement mortar needs to be developed.

The tests carried out in the Institute of Building Engineering at Wrocław University of Technology, although quite extensive, have not exhausted the full range of experiments to which the investigated special polymerized sulfur composite should be subjected in order to have complete certainty that it can provide effective surface protection against corrosion for concrete and cement mortar. Also a simple and fast technology of applying the composite to the surface of concrete in building practice needs to be developed also tests in temperatures below $0^{\circ} \mathrm{C}$ and $<0^{\circ} \mathrm{C}\left(-10 \div-20^{\circ} \mathrm{C}\right)$ inclusive allotropy and influence on fire protection.

The process of special polymerized sulfur composite applied as the industrial waste material production is a thermal treatment process in the temperature of about $150-155^{\circ} \mathrm{C}$. The result of such treatment is special polymerized sulfur composite in a liquid state.

Special polymerized sulfur in a liquid state is mixed with previously heated extender. In the paper there is presented development of the special polymerized sulfur composites as the industrial waste material, along with the practical uses in building industry.

The test results presented in this paper indicate that the special polymerized sulfur composite can provide surface protection against corrosion for concrete and cement mortar. Special polymerized sulfur composite have not been used for this purpose before.

Recent research has led to the development of durable special polymerized sulfur mortars, concretes, and coatings. All of the methods of using special polymerized sulfur as a binder for rigid concrete rely on the reaction of one or more modifiers to stabilize, in the hardened state, at least a portion of the special polymerized sulfur in its less brittle, less dense form. The durability of the concrete produced appears to depend on the modifying system used. In all cases the special polymerized sulfur must be heated to a liquid state to react with the modifier and to mix with and coat the aggregate and filler.

Special polymerized sulfur - impregnated concrete and cement mortar can develop high strength, attains strength in 0.5 hours, requires no special curing, resists acids and organic liquids, has no known undesirable reactions with aggregates, and requires no limitation on the ambient temperature at the time of placement. When its use becomes economically feasible, concrete impregnated special polymerized sulfur will be an excellent material for use in pavement repairs and bridge deck overlays.

Solidified impregnate in the small pores of solids are normally in metastable equilibrium. Spatial restrictions prohibit the formation of regular crystal habit. Because of the formation of non-crystalline modifications the free energy is increased. In addition, owing to the large surface-to-volume ratio the surface-free energy is also large. In the absence of concave menisci or strong interaction with the matrix that would reduce the energy, the tendency for spontaneous exudation from the pores is increased.

Special polymerized sulfur - does not interact strongly with siliceous surfaces, so that water or other liquids can penetrate the porous network and adsorb on the substrate surface, weakening further the interaction between it and sulfur. Water adsorbs also on sulfur, creating a lubricating effect and high stresses due to surface energy decrease. Both effects facilitate extrusion and the latter cause's destruction.

Because of the relatively slow penetration of water, non - isotropic expansion creates strains beyond the elastic limits. Impregnated porous solids of small size can be successfully utilized for predicting the behavior of large sized systems.

It is recommended that any further data collection by the Research Council include on-site inspection of placements and interviews with highway department people involved. It is recommended that any steps towards the widespread utilization of special polymerized sulfur in Poland await the results of research on the use of it as a patching material, a bridge deck overlay, or in other applications. The Research Council should remain alert to any developments in this field. Unless detailed instructions for the mixing and placing of special polymerized sulfur impregnated concrete become available, it will probably be necessary for the first sizable Poland placement of this material to be made by a contractor experienced in its use. Such a placement should be made with Poland and Russia aggregates and probably in a zone having a severe climate.

\section{References}

1. Almaslow A, Ratnam CT, Ghazali MJ, Talib RJ, Azhari CH (2013) Effects of electron-beam and sulfur crosslinking of epoxidized natural rubber on the friction performance of semimetallic friction materials. Composites Part B: Engineering 54: 377-382.

2. Antonowicz R, Bywalski CZ, Kamiński M (2014) Analysis of loads and structural 
capacity of steel silo with corrugated wall for pelleted material. Journal of Civil Engineering and Management 20: 372-379.

3. Bednarz $Ł$, Górski A, Jasieńko J, Rusiński E (2011) Simulations and analyses of arched brick structures. Automation in Construction 20: 741-754.

4. Biegus A (2013) Calculation of lateral bracing for cantilever and multispan girders. Archives of Civil and Mechanical Engineering 13: 99-103.

5. Bień J, Hoła J, Sadowski $Ł$ (2013) Modern NDT techniques in diagnostics of transport infrastructure concrete structures. e-Journal of Nondestructive Testing and Ultrasonics 18: 1-10.

6. Bień J (2011) Modelling of structure geometry in bridge management systems. Archives of Civil and Mechanical Engineering 11: 519-532.

7. Błaszczyński TZ (2011) The influence of crude oil products on RC structure destruction. Civil Engineering and Management 17: 146-156.

8. Bywalski Cz, Kamiński M (2013) Rheological strains in concrete modified with steel fibre reinforcement. Journal of Civil Engineering and Management 19: 656-664.

9. Bywalski Cz, Kamiński M (2011) Estimation of the bending stiffness of rectangular reinforced concrete beams made of steel fibre reinforced concrete. Archives of Civil and Mechanical Engineering 11: 553-571.

10. Czarnecki L, Garbacz A (1995) Evaluation of polymer coating-crack-bridging ability. International Colloquium "Industrial Floors" 95, Esslingen.

11. Czarnecki L, Emmons PH (2002) Repair and protection of concrete structures (in Polish), Wydawnictwo Polski Cement, Kraków.

12. Czarnecki L (2010) Polymer Concretes. Cement-Wapno-Beton 15: 63-85.

13. Dawood ET, Ramli M (2014) The effect of using high strength flowable system as repair material, Composites Part B: Engineering 57: 91-95

14. Gorzelańczyk T, Hoła J, Sadowski Ł, Schabowicz K (2013) Methodology of nondestructive identification of defective concrete zones in unilaterally accessible massive members. Civil Engineering and Management 19: 775-786.

15. Gorzelańczyk T, Hoła J (2011) Pore structure of self-compacting concretes made using different superplasticizers. Archives of Civil and Mechanical Engineering 11: 611-621.

16. Gosowski B, Gosowski M (2014) Exact solution of bending problem for continuous sandwich panels with profiled facings. Journal of Constructional Steel Research 101: 53-60.

17. Gosowski B, Gosowski M (2012) Distributional solutions of bending problems for continuous sandwich panels with thin facings. Archives of Civil and Mechanical Engineering 12: 13-22.

18. Helmerich R, Niederleithinger E, Trela C, Bień J, Kamiński T (2012) Multi-tool inspection and numerical analysis of an old masonry arch bridge. Structure and Infrastructure Engineering 8: 27-39.

19. Helmerich R, Bień J (2012) 100 Jahre Kaiserbrücke/Grunwaldzki-Brücke in Wrocław (Polen). Stahlbau 81: 156-159.

20. Hoła J, Matkowski Z, Schabowicz K, Sikora J, Nita K (2012) Identification of moisture content in brick walls by means of impedance tomography. Compel 31:1774-1792.

21. Hoła J, Sadowski $\measuredangle$, Schabowicz K (2011) Nondestructive identification of delaminations in concrete floor toppings with acoustic methods. Automation in Construction 20: 799-807.

22. Hoła J, Schabowicz K (2010) State-of-the-art non-destructive methods for diagnostic testing of building structures-anticipated development trends. Archives of Civil and Mechanical Engineering 10: 5-18.

23. Hoła J, Książek M (2009) Research on usability of sulphur polymer composite for corrosion protection of reinforcing steel in concrete. Archives of Civil and Mechanical Engineering 9: 47-59.

24. Hoła J, Schabowicz K (2005) Methodology of neural identification of strength of concrete. ACI Materials Journal 102: 459-464.

25. Hoła J, Schabowicz K (2005) New technique of nondestructive assessment of concrete strength using artificial intelligence. NDT and E International 38: 251-259

26. Jankowski L, Jasieńko J, Nowak T (2010) Experimental assessment of CFRP reinforced wooden beams by 4-point bending tests and photoelastic coating technique. Materials and Structures 43: 141-150.

27. Jasieńko J, Nowak T (2014) Solid timber beams strengthened with steel plates - experimental studies. Construction and Building Materials 63: 81-88

28. Jasieńko J, Nowak T, Bednarz $Ł$ (2014) Baroque structural ceiling over the Leopoldinum Auditorium in Wrocław University. International Journal of Architectural Heritage 8: 269-289.

29. Jasieńko J, Nowak T, Bednarz $Ł$ (2010) Wrocław University’s Leopoldinum Auditorium-tests of its ceiling and a conservation and strengthening concept. Advanced Materials Research 133: 265-270.

30. Jasieńko J, Bednarz $Ł$, Nowak T (2009) The effectiveness of strengthening historic brick vaults by contemporary methods. Proceedings of the International Conference on Protection of Historical Buildings, Rome, Italy.

31. Jasieńko J, Nowak T, Bednarz $Ł$ (2009) Reinforcement of bent timber beams in historic buildings. Proceedings of the International Conference on Protection of Historical Buildings, Rome, Italy.

32. Jasieńko J, Stawiski B (2001) Analysis of cracking plane geometry in old sandstone columns. Materials and Structures 34: 248-252.

33. Kamiński M, Kusa E, Demski D (2012) Time-dependent behaviour of CFRPstrengthened reinforced concrete beams. Proceedings of Concrete Solutions, 4th International Conference on Concrete Repair, Dresden, Germany.

34. Kamiński M, Pawlak W (2011) Load capacity and stiffness of angular cross section reinforced concrete beams under torsion. Archives of Civil and Mechanical Engineering 11: 885-903.

35. Kamiński M, Musiał M, Ubysz A (2011) Eigen frequencies of the reinforced concrete beams - methods of calculations. Journal of Civil Engineering and Management 17: 278-283.

36. Klakočar-Ciepacz M, Ksiażek M (2003) Investigation of the intensity of corrosion processes influence by tensile stress for reinforcing steel covered with sulphuric coating. Chemicals in sustainable agriculture, Jesenik, 761-765.

37. Kmiecik P, Kamiński M (2011) Modelling of reinforced concrete structures and composite structures with concrete strength degradation taken into consideration. Archives of Civil and Mechanical Engineering 11: 623-636.

38. Kruszyna M, Mackiewicz P, Szydło A (2006) Influence of pedestrians entry process on pedestrian delays at signal-controlled crosswalks. Journal of Transportation Engineering 132: 855-861.

39. Książek M (2014) Biological corrosion of the sandstone of the quay of the river of Odra in Wrocław. Engineering Failure Analysis 44: 338-344.

40. Ksiazżek M (2014) The biocorrosion of city sewer collector impregnated special polymer sulfur binder-polymerized sulfur applied as the industrial waste material. Construction and Building Materials 68: 558-564.

41. Książek M (2014) The influence of penetrating special polymer sulfur binder - polymerized sulfur applied as the industrial waste material on concrete watertightness. Composites Part B, Engineering 62: 137-142.

42. Ksiażek M (2014) The evaluate tendencies of corrosion process for reinforcing steel when covered with special polymer sulfur coating. Engineering Failure Analysis 39: 1-11.

43. Książek M (2014) The experimental investigations of propriety and applies in the building special coating-sulphur polymer composite as the industrial waste material. Composites Part B, Engineering 58: 378-385.

44. Książek M (2014) City sewer collectors biocorrosion. Central European Journa of Engineering 4: 398-407.

45. Książek M (2014) The experimental research on properties, structures and applies polymer sulfur composites as the industrial waste material in the industry objects. Materials and Structures.

46. Książek M (2013) The intensity of corrosion processes influenced by tensile stress for reinforcing steel covered with sulphur polymer composite applied as industrial waste material. Composites. Part B, Engineering 45: 1126-1132.

47. Książek M (2013) The experimental and innovative research on intensity of corrosion processes influenced by tensile stress for reinforcing steel covered with sulphur polymer composite applied as industrial waste material. Advanced Science Letters 19: 247-251.

48. Ksiażek M (2012) Experimental research on the surface protection of concrete by polymer sulfur composite. Magazine of Concrete Research 64: 945-955. 
Citation: Książek M (2015) The Experimental Research on Special Polymerized Sulfur Composite-Impregnated Concrete and Cement Mortar. J Material Sci Eng 4: 160. doi:10.4172/2169-0022.1000160

Page 8 of 8

49. Ksiazzek M (2011) The experimental and innovative research on usability of sulphur polymer composite for corrosion protection of reinforcing steel and concrete. Composites. Part B, Engineering 42: 1084-1096.

50. Ksiażek M (2001) The mechanical destruction of sulphur composites [Niszczenie mechaniczne kompozytów siarkowych]. Prace Naukowe Instytutu Budownictwa Politechniki Wroclawskiej.

51. Książek M (1999) The sulphur binders-Their potential possibilities of using in buildings [Spoiwa siarkowe-lch potencjalne możliwości zastosowań w budownictwie]. Prace Naukowe Instytutu Budownictwa Politechniki Wroclawskiej.

52. Lorenc W, Kożuch M, Seidl G (2013) Zur Grenztragfähigkeit von Verbunddübeln mit Klothoidenform. Stahlbau 82: 196-207.

53. Łowińska-Kluge A, Błaszczyński T (2012) The influence of internal corrosion on the durability of concrete. Archives of Civil and Mechanical Engineering 12: 219-227.

54. Ramli M, Tabassi AA, Hoe KW (2013) Porosity, pore structure and water absorption of polymer-modified mortars: An experimental study under different curing conditions, Composites Part B: Engineering 55: 221-233.

55. Maksymowicz M, Cruz PJS, Bień J (2011) Load capacity of damaged RC slab spans of railway-bridges. Archives of Civil and Mechanical Engineering 11: 963-978

56. Vlahović MM, Jovanić PB, Martinović SP, Boljanac TD, Volkov-Husović TD (2013) Quantitative evaluation of sulfur-polymer matrix composite quality. Composites Part B: Engineering 44: 458-466.

57. Nowak T, Jasieńko J, Czepiżak D (2013) Experimental tests and numerical analysis of historic bent timber elements reinforced with CFRP strips. Construction and Building Materials 40: 197-206.

58. Nowak T, Jankowski L, Jasieńko J (2010) Application of photoelastic coating technique in tests of solid wooden beams reinforced with CFRP strips. Archives of Civil and Mechanical Engineering 10: 53-66.
59. Pawlak W, Kamiński M (2012) Cracking of reinforced concrete beams under torsion - theory and experimental research. Archives of Civil and Mechanical Engineering 12: 368-375.

60. Polakowski K, Sikora J, Filipowicz S, Hoła J, Schabowicz K (2007) Wall humidification imaging by ultrasonic tomography. Przegląd Elektrotechniczny 5: 116-121.

61. Ruta P, Szydło A (2005) Drop-weight test based identification of elastic half space model parameters. Journal of Sound and Vibration 282: 411-427.

62. Sadowski $\measuredangle$, Hoła J (2014) New nondestructive way of identifying the values of pull-off adhesion between concrete layers in floors. Journal of Civil Engineering and Management 20: 561-569.

63. Schabowicz K, Hoła J (2012) Nondestructive elastic-wave tests of foundation slab in office building. Materials Transactions 53: 296-302.

64. Seidl G, Stambuk M, Lorenc W, Kołakowski T, Petzek E (2013) Wirtschaftliche Verbundbauweisen im Brückenbau - Bauweisen mit Verbunddübelleisten. Stahlbau 82: 510-521.

65. Szydło A, Mackiewicz P (2005) Asphalt mixes deformation sensitivity to change in rheological parameters. Journal of Materials in Civil Engineering 17: 1-9.

66. Thomas C, Cimentada A, Polanco JA, Setien J, Mendez D (2013) Influence of recycled aggregates containing sulphur on properties of recycled aggregate mortar and concrete. Composites Part B-Engineering 45: 474-485.

67. Trapko T, Kamiński M, Musiał M (2012) Investigations on rheological strains of compressed concrete elements strengthened with external composite reinforcement CFRP. Composites. Part B, Engineering 43: 1417-1424.

68. Liu XB, Liu HQ, Liu YF, He XM, Sun CF (2013) Effects of temperature and normal load on tribological behavior of nickel-based high temperature selflubricating wear-resistant composite coating, Composites Part B: Engineering 53: 347-354. 